\title{
多能性幹細胞の神経系分化誘導と金属による神経毒性研究への応用
}

\author{
谷口結基, ${ }^{a}$ 戸邊隆夫, ${ }^{a}$ 速水英明, ${ }^{a}$ 岡本誉士典, ${ }^{*}, a$ \\ 植田康次, ${ }^{a}$ 高田達之, ${ }^{b}$ 小嶋仲夫 ${ }^{a}$
}

\section{Neural Differentiation of Pluripotent Stem Cells and Application for Metal-induced Neural Toxicity Study}

\author{
Yuki Taniguchi, ${ }^{a}$ Takao Tobe, ${ }^{a}$ Hideaki Hayami, ${ }^{a}$ Yoshinori Okamoto, ${ }^{*, a}$ \\ Koji Ueda, ${ }^{a}$ Tatsuyuki Takada, ${ }^{b}$ and Nakao Kojima ${ }^{a}$ \\ ${ }^{a}$ Faculty of Pharmacy, Meijo University; 150 Yagotoyama, Tempaku-ku, Nagoya 468-8503, \\ Japan: and ${ }^{b}$ Department of Pharmaceutical Sciences, Ritsumeikan University; \\ 1-1-1 Nojihigashi, Kusatsu, Shiga 525-8577, Japan.
}

(Received January 30, 2014)

\begin{abstract}
Metals are effectively used in biological systems under the strict regulation for exploiting their specific and broad reactivities. For example, manganese $(\mathrm{Mn})$ can induce catecholamines-mediated oxidative biological damage in cooperation with iron $(\mathrm{Fe})$ and/or copper $(\mathrm{Cu})$. In children, the damage could induce developmental disorders such as attention deficit hyperactivity disorder (ADHD). We hypothesize that infant neurons are more labile to metals than adult ones due to the prematured protection systems and sensitive differentiating cells. An experimental system reconstituting neural differentiation is expected to assess the influences of endogenous/exogenous factors including metals. In this study, we investigated an impact of $\mathrm{Mn}$ together with $\mathrm{Fe}$ and dopamine (DA) on neural differentiation of mouse embryonic stem cells (mESCs). The differentiation of mESCs was initiated by embryoid bodies (EBs) formation in the presence of all-trans retinoic acid, and then EBs were treated with Mn, Fe and/or DA. Then, the mRNA levels of neural differentiation marker genes (Nestin, Emx2, Mtap2, Th, Olig2 and Gfap) were examined using realtime RT-PCR analysis. Mn or DA alone reduced Mtap2, Th and Olig2 expression levels and increased Nestin. Moreover, combined treatment of Mn and DA also increased Nestin expression level. On the other hand, Fe alone reduced Mtap2, Th and Olig2 expression levels, and increased Emx2. Combined treatments of Fe with Mn or DA also tended to increase Emx2 expression level. These effects emerged at about 100 times less concentration than that inducing cytotoxicity in human neuroblastoma. The present study showed that Mn inhibits neural development, and that our mESCs system can be a useful tool to elucidate the toxicity mechanism as well as to evaluate the effects of metals and chemicals on differentiating cells.
\end{abstract}

Key words_— mouse embryonic stem cell; neurotoxicity; cell differentiation; neural development

\section{1. 背景}

生命は，ある選択律で取り込んだ金属の特有かつ 多様な性質を有効に利用することによって，代謝や 呼吸, シグナル伝達などの様々な生体反応を駆動し ている.1)これらの金属は，通常その動態が綿密に 制御されており悪影響を及ぼすことはない。しかし ながら，過剩曝露や個体感受性差などによりこれら

The authors declare no conflict of interest.

$a$ 名城大学薬学部（T468-8503 名古屋市天白区八事山 $150)$, b立命館大学薬学部（厂5 525-8577 滋賀県草津市 野路東 1-1-1)

*e-mail: okmt@meijo-u.ac.jp

本総説は, 日本薬学会第 133 年会シンポジウム GS-2

で発表した内容を中心に記述したものである.
の制御システムが破綻した場合，金属毒性を示すよ うになり，種々の疾病の発症につながるものと考え

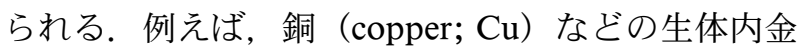
属は, カテコール類と反応して活性酸素種（reactive oxygen species; ROS）を産生し, 酸化的 DNA 損傷を引き起こして発がんを誘発することもあ る. ${ }^{2,3)}$ 特に, 活発な呼吸はしながらも増殖分裂によ る DNA 修復が行われていない神経細胞は, 酸化ス トレスに対して脆弱であると考えられている。 われ われの研究グループでは, パーキンソン病に類似し た症状を引き起こすマンガン (manganese; Mn) に ついて, 酸化ストレス惹起と発症との観点から詳細

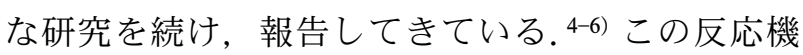


構としては，Mn が鉄（iron; Fe）あるいは $\mathrm{Cu}$ と 協働して，生体内神経伝達物質であるドパミン (dopamine; DA) などのカテコールアミン類の酸 化・環化を促進し, ROS の生成を増強することが 重要と考えている。このように金属による毒性の発 現は, ある種の環境変化に伴って，複数の化合物と 金属との複合的な反応によって引き起こされている ことが強く示唆される.

一方，子どもを対象にした近年の疫学的調査によ れば，環境中の Mn に曝露されると，不注意・多 動性・衝動性を特徴とする発達障害及び日常生活や 学習に支障をきたす注意欠陥多動性障害（attention deficit hyperactivity disorder; ADHD) の発症率に関 連してくることが報告されている. ${ }^{7-9)}$ その要因と して，子どもは血液脳関門などの防御システムが未 熟であるため, Mn が脳に移行し易く，上記のカテ コールアミン類との協働作用による悪影響を受け易 いことが考えられる。加えて, 神経系がまだ発達段 階にあるため, 神経細胞死が引き起こされる濃度よ り低濃度でも, 神経前駆細胞などでは分化・発達異 常が生じている可能性がある。この神経分化・発達 異常を実験的に再構成することができれば，神経系 に影響を及ぼす金属を始めとする様々な化学物質の 分化過程への影響を評価することができる.

こうした新たな評価システムに応用が考えられる 多能性幹細胞は, 実験的に純粋培養することができ る正常幹細胞であり, 適切な培養環境で分化誘導す ることにより，様々な機能性細胞に分化させること ができる，機能性細胞の中でも，神経細胞への分化 は比較的に容易であり，分化・発達過程に影響を及 ぼす化学物質のスクリーニング系として有用であ る.そこでわれわれは以下のように，マウス肧性幹 細胞（mouse embryonic stem cells; mESCs）を用い て，神経系分化誘導に対して金属が引き起こす影響 を評価するシステム構築に取り組んでいる.

\section{2. 結果 · 考察}

マウス胎児性線維芽細胞 (mouse embryonic fibroblast; MEF）を支持細胞として mESCs を維持培養 し， mESCs を凝集させて胚様体（embryoid bodies; EBs）を作製した. EBs 形成と同時に化学物質処理 (DA $1 \mu \mathrm{M}, \mathrm{Mn} 2 \mu \mathrm{M}, \mathrm{Fe} 2 \mu \mathrm{M}$ の単独あるいは併用) を開始し, 7 日間培養後, 神経系分化マーカー遺伝 子 (Nestin, 神経幹細胞; Emx2, 神経前駆細胞 ;



Fig. 1. Evaluation of Test Chemicals Neurotoxicity Using mESCs

Mtap2，神経細胞；Th，DA 作動性神経; Olig2, オリゴデンドロサイト；Gfap，アストロサイト） の発現強度を解析することで試験化合物による神経 細胞分化に対する影響を評価した（Fig. 1).

ESCs の神経分化誘導剂として知られているレチ ノイン酸（all-trans retinoic acid; RA, $1 \mu \mathrm{M}$ ）をEBs に加えると mESCs が神経系へ分化し，種々の神経 系分化マーカー遺伝子が発現誘導されることを確認 している．この神経分化誘導条件に Mn， Fe 及び DAを併用した場合に各試験物質が神経細胞分化に 与える影響を検討した. Mn と DA の単独処理にお いて Mtap2, Th, Olig2 の発現が減少し, Nestinの 発現が増加した。 さらに, Mn と DA の併用処理に おいては明らかにNestin の発現が増加した。この ことから, Mn と DA は mESCs の Nestin の発現を 増加させるが，その先のマーカーの発現抑制が起こ ることが示唆された。一方, Fe の単独処理におい てはMtap2，Th，Olig2 の発現は，Mn及び DA と 同様に減少し, Emx2 の発現が増加した。また, $\mathrm{Fe}$ に Mn や DA を併用処理した場合でもEmx2 の発 現が増加傾向を示した。 このことから Fe はNestin から $E m x 2$ の発現を促進するが, $E m x 2$ 以降の発現 抑制が起こると考えられる。また，本実験系では Gfap の発現はすべての処理においてほとんどみら れなかった。 ヒト神経芽腫細胞 SH-SY5Y 細胞に対 する細胞死の誘導には，DA $200 \mu \mathrm{M}, \mathrm{Mn}$ 及び Fe $400 \mu \mathrm{M}$ という高濃度を必要としたのに対して, mESCs においては DA $1 \mu \mathrm{M}, \mathrm{Mn}$ 及び Fe $2 \mu \mathrm{M}$ と いう低濃度で上記の分化異常を示した。 今回の実験 
から，以前の研究で報告していた「 $\mathrm{Mn}$ は $\mathrm{Fe}$ と協 働して酸化的 DNA 損傷を増強させる」ことに加え て，「Mn は神経系の発達段階において神経幹細胞 の分化を抑制する」という新しい知見が得られた.

今後, Mn による多面的な毒性メカニズムの解明に つながるものと期待される.

本研究では, Mn を例に挙げて神経分化に対する 影響を評価することができた．また，その影響は， これまでの細胞死というエンドポイントと比較して 100 分の 1 程度という低濃度で観察できる.したが って，本実験系は神経分化過程に及ぼす化学物質の 影響をより鋭敏に確認でき，化学物質のスクリーニ ングや毒性メカニズムなどを解明するために有用な ツールになり得るものと考えられる。

\section{謝辞 本研究の遂行にあたりご協力頂いた近藤} 沙和美さん, 山田育代さん, 岩井宏徳さん, 松田栄 二さん，そして本稿執筆に際し貴重なご助言を頂い た方々に，ここに記して感謝します。

\section{REFERENCES}

1) Andreini C., Bertini I., Cavallaro G., Holliday
G. L., Thornton J. M., J. Biol. Inorg. Chem., 13, 1205-1218 (2008).

2) Oikawa S., Hirosawa I., Hirakawa K., Kawanishi S., Carcinogenesis, 22, 1239-1245 (2001) .

3) Midorikawa K., Uchida T., Okamoto Y., Toda C., Sakai Y., Ueda K., Hiraku Y., Murata M., Kawanishi S., Kojima N., Chem. Biol. Interact., 150, 271-281 (2004).

4) Ando M., Ueda K., Okamoto Y., Kojima N., J. Health Sci., 57, 204-209 (2011).

5) Nishino Y., Ando M., Makino R., Ueda K., Okamoto Y., Kojima N., Neurotox. Res., 20 , 84-92 (2011).

6) Ueda K., Ando M., Okamoto Y., Kojima N., J. Res. Inst. Meijo Univ., 12, 75-80 (2013) .

7) Barlow P. J., Med. Hypotheses, 11, 309-318 (1983).

8) Woolf A., Wright R., Amarasiriwardena C., Bellinger D., Environ. Health Perspect., 110, 613-616 (2002).

9) Bouchard M., Laforest F., Vandelac L., Bellinger D., Mergler D., Environ. Health Perspect., 115, 122-127 (2007). 